\title{
Perancangan Permainan Simulasi (Game Simulation) Untuk Menilai Tingkat Kematangan Strategi Teknologi Informasi terhadap Strategi Bisnis Dengan Metode IT Balanced Scorecard dan Maturity Model COBIT 4.1
}

\author{
Agnes Karina Pritha Atmani \\ Program Studi Animasi, Fakultas Seni Media Rekam \\ Institut Seni Indonesia Yogyakarta \\ e-mail: agneskarina@gmail.com
}

\begin{abstract}
Abstrak
Keselarasan strategi Teknologi Informasi terhadap strategi bisnis sangat dibutuhkan untuk mencapai tujuan bisnis. Pencapaian keselarasan strategi, sebagai suatu proses yang berkelanjutan, membutuhkan dukungan dari Top Management dan fungsi-fungsi lain dalam perusahaan. Penilaian kematangan tingkat keselarasan strategi TI terhadap strategi bisnis akan digunakan sebagai alat ukur untuk menilai tingkat keselarasan strategi TI terhadap strategi bisnis. Nilai tersebut akan digunakan sebagai langkah awal untuk tindakan perbaikan berkelanjutan.

Penggunaan permainan simulasi merupakan gabungan dari dua metode experiential learning, yaitu simulasi (simulation) yang dapat melakukan peniruan dari suatu perilaku atau proses dan permainan (game) yang merupakan aktifitas yang kompetitif. Melaui Experiential Learning pengguna permainan dapat melakukan pembelajaran secara aktif dan memperoleh pengetahuan, pemahaman, dan pandangan baru mengenai suatu hal.

Penilaian kematangan tingkat keselarasan strategi TI terhadap strategi bisnis akan mengacu pada konsep Strategic Alignment Model yang diperkenalkan oleh Henderson dan Venkatraman dan IT-Balanced Scorecard yang dikembangkan Grembergen dan Bruggen. Keduanya memberikan panduan mengenai model-model yang dapat diimplementasikan di perusahaan. Sedangkan penilaian kematangannya berdasarkan kriteria Maturity Model COBIT 4.1 (Control Objective on Information and related Technology)
\end{abstract}

Kata kunci: Permainan Simulasi, Experiential Learning, Teknologi Informasi, Strategi TI, Strategi Bisnis, Strategic Alignment Model-Henderson \& Venkatraman, IT-Balances Scorecard - Grembergen \& Bruggen, dan COBIT 4.1 Maturity Model. 
Agnes Karina Pritha Atmani

Perancangan Permainan Simulasi (Game Simulation) Untuk Menilai Tingkat Kematangan

Strategi Teknologi Informasi terhadap Strategi Bisnis Dengan Metode

IT Balanced Scorecard dan Maturity Model COBIT 4.1

\begin{abstract}
The alignment of Information Technology strategy with business strategy is important to achieve business objectives. Strategy alignment, as an ongoing process, requires support from Top Management as well as from other functions in the company. The assessment of maturity level on the alignment of Information Technology with business strategy becomes the measuring tool to assess the alignment of Information Technology strategy with business strategy. The score, then, will be used as starting point in accomplishing continuous repair action.

The use of game simulation is a combination of two experiential learning methods, namely simulation that can perform the imitation of a behavior or process and game which is a competitive activity. Through Experiential Learning game users can actively learn and gain new knowledge, insights, and insights about things.

The assessment of maturity level of the aligment of Information Technology with business strategy which applied Strategic Alignment Model concept introduced by Henderson and Venkatraman and IT-Balanced Scorecard by Grembergen and Bruggen. Both have given guidelines about several models that can be implemented at company. Moreover, in order to assess the maturity level, this research uses Maturity Model COBIT 4.1 (Control Objective on Information and related Technology.
\end{abstract}

Keywords: Information Technology, Game Simulation, Experiential Learning, Information Technology strategy, Business strategy, Strategic Alignment Model-Henderson \& Venkatraman, IT-Balanced Scorecard-Grembergen \& Bruggen, and COBIT 4.1 Maturity Model.

\title{
Pendahuluan
}

Pemanfaatan Teknologi Informasi (TI) dapat memberikan nilai tambah pada sebuah perusahaan, dengan memberikan keunggulan kompetitif dalam pangsa pasar yang dituju sebuah perusahaan. Teknologi Informasi tersebut sudah dapat memberikan nilai tambah atau belum, dapat diketahui dengan mengukur keselarasan antara strategi TI terhadap strategi bisnis. Keselarasan strategi TI terhadap strategi bisnis diperlukan agar tujuan bisnis tercapai dan investasi yang dilakukan dalam TI dapat memberikan manfaat yang besar. Penilaian keselarasan antara Strategi TI terhadap strategi bisnis dapat diukur tingkat kematangannya, dan dapat digunakan sebagai alat ukur untuk menilai tingkat keselarasan strategi TI terhadap strategi bisnis.

Nilai tersebut akan digunakan sebagai langkah awal untuk tindakan perbaikan berkelanjutan. Penilaian keselarasan strategi TI terhadap strategi bisnis akan mengacu pada konsep Strategic Alignment Model yang diperkenalkan oleh Henderson dan Venkatraman dalam IBM System Journal, Vol.38 no. dua dan tiga, 